\title{
Tajunnan olemassaolo ja omalakisuus
}

\section{Lasse Rauhala. Tajunnan itsepuolustus. Yliopisto- paino, Helsinki 1995.}

Suomalaisen fenomenologian hala on omistanut kirjansa Tajunnan itsepuolustus ihmisen tajunnallisen olemispuolen itsenäisen olemassaolon puolustamiselle. Rauhalan vakiinnuttaman, inmistä koskevan ontologian perusolettavuudethan ovat situationaalisuus, kehollisuus ja tajunnallisuus. Vaikka kehon suhtautuneisuus ajallis-paikallismateriaaliseen elämäntilanteeseen onkin tajunnallisen tapahtumisen edellytys, tajuntaa ei kuitenkaan voida Rauhalan mukaan koskaan palauttaa kehon tai situaation toimintoihin. $\mathrm{N}$ iinpä tajunnallisuus tulisikin nähdä omana inmisen kokonaisuutta Iuonnehtivana peruskategoriana, joka laadullisen erilaisuutensa ja loogisen eritasoisuutensa vuoksi ansaitsee itsenäisen olemassaolon kehollisuuden ja situationaalisuuden rinnalla.

Tämän ihmisen kokonaisuuden Rauhala nimeää käsitteellä situationaalinen säätöpiiri, jossa siis inmisen eri olemuspuolet eli stuaatio, kehoja tajunta ovat vastavuoroisesti sisäkkäin toistensa olemassaolon ehtoina ja toteutumina. K oska tällaisessa ihmisen mallissa eri osapuolten keskinäinen riippuvuus ilmenee myös siten, että ne edellyttävät toisensa ollakseen itse olemassa, perinteisen kausaalisuuden idean soveltamisyritykset inmistä jäsentävänä ajattelumallina johtavat melkoisiin vaikeuksiin.

Vaikka filosofisen analyysin avulla voidaankin Rauhalan osoittamalla tavalla määritellä situationaalisen säätöpiirin eri osat ja niiden perusluonne, silti noita eri osia ei voida koskaan irrottaa toisistaan esinemäisessä mielessä kadottamatta ihmisen kokonaisuuden erityislaatuisuutta. Toisin sanoen, Rauhalan koseptiossa situationaalisen säätöpiirin eri osa-alueet ovat toisiinsa kietoutuneita ja osittain sisältävät toisensa myös käsitteellisessä mielessä. E ri olemuspuolien välisen tapahtumisen voidaankin niiden yhteenkietoutuneisuuden vuoksi ajatella etenevän toisiinsa nähden dialektisena eli vastavuoroisena prosessina. Tätä kokonaisprosessin etenemistä on totuttu mallintamaan hermeneuttisen kehän avulla, jossa mikään tilanne ei koskaan toistu aiemman kaltaisena, vaikka kulloinenkin nykytilanne rakentuukin aiemman historiallisen faktisuuden varaan. Johann Wolfgang von $G$ oethen sanoin vapaasti lainaten voitaisiinkin todeta, että on vain ikuisesti uutta, joka modostuu mennessyden aineksista.

$T$ ajunnan itsenäistä olemassaoloa Rauhala perusteleekin juuri filosofis-ontologisen argumentoinnin avulla. Tajunnan olemassaoloa ei nimittäin perustellusti voida kieltää, vaikka empiirinen tutkimus ei olekaan onnistunut selittämään kokemuk- sellisuutta omien neurobiologisten käsitejärjestelmiensä ja malliensa avulla. IIman tajuntaa tajunnan olemassaolon problematisoiminenkin lienee mahdotonta. Tieto-opillisessa mielessä tajunta näyttäytyykin kehoa ja aivoja ensisijaisempana, sillä vasta tajunnallisten merkityskokemusten (eli kysymysten ja hypoteesien asettamisen sekä niihin vastaamista edellyttävien tutkimustulosten tulkintojen) kautta esimerkiksi ajattelun neurofysiologisten vastineiden kuvaaminen on mahdollista. Kokemuksen sidonnaisuus aivofysiologiaan ei siis oikeuta samaistamaan näitä toisiinsa. Rauhalan mukaan tajunnan tutkimuksen ydin kiteytyykin merkityksen ongelmassa eli kokemuksen ehtojen ja itse kokemuksen välisessä loogisessa tyyppierossa. Fysiologisista prosesseista poiketen tajunta voi siis omalaatuisen mielellisyytensä piirissä oivaltaa itse omat toteutumisehtonsa ja lainalaisuutensa.

$\mathrm{R}$ auhalan mukaan tajunta on prosessi, jossa merkitykset kehkeytyvät, asettuvat keskinäisiin suhteisiin ja muuttuvat jatkuvasti. M erkitykset, joiden aiheet ilmenevät kehosta ja situaatiosta, koetaan siten tajunnallisina heijastumina ja jäsennyksinä tajunnan eli kokemuksen kokonaisuuden piirissä. Rauhala kuvaa tajuntaa käsitteellisellä mallilla, jonka operatiiviset perusyksiköt eli mielen (noemat) järjestyvät sisältämiensä merkitysten ohjaamina. Tämän järjestymisen periaatteena ja samalla 
tajunnan perusluonteena on Rauhalan terminologiassa mielellisyys. Mielellisyys tajuntaa luonnehtivana käsitteenä kattaa sekä perinteisen fenomenologisen intentionaalisuuden eli tajunnan eriasteisen suuntautuneisuuden johonkin yksilöitävissä olevaan (ilmiö, esine, asia, idea jne) että niin sanotun epäintentionaalisuuden eli periaatteessa mihinkään viittaamattomat tunnelmalliset kokonaistilat connellisuus, tyytyväisyys, ikävystyneisyys, autuus, pyhyys, epätoivo jne).

\section{Ihmisyksilön ainutkertaisuus}

P ohdintojensa perusteella Rauhala ottaa yleisesti kantaa myös ihmistutkimuksen nykytilaan. Rauhalan ajattelun filosofisena viitekehyksenähän on Edmund Husserlin ja Martin Hejdeggrin elämäntöiden varaan rakentuva eksistentiaaliseksi fenomenologiaksi kutsuttu ja erityisesti inmiseen keskittyvä ajattelutapa. I hmisyksilön ainutkertaisuuden ja tämän subjektiivisen merkitysmaailman korostaminen johtaakin tilastollisiin keskiarvolakeihin nojautuvasta metodiikasta paljon perso onakohtaisempaan tutkimusotteeseen. Tällaisen ideografisen persoonatutkimuksen keskeisenä selvittelyn kohteena Rauhala näkee lähinnä sen, miten ihmisyksilöstä on tullut geenien ja muiden situationaalisesti määräytyneiden olemisehtojen vallitessa se, mikä hän on, ja miten häntä voidaan niiden asettamien mahdollisuuksien rajoissa kehittää - epäsuotuisista piirteistä vapauttaen ja myönteisiä puolia vahvistaen - kohti rikkaampaa ja täydellisempää inhimilli- syyttä. Tämänkaltaisessa prosessissahan persoona itse on samalla kertaa tutkimuskohde, tutkimusprosessi, tutkimustulosten ilmentymä, muutostapahtuma ja siten myös kehityksen tulos.

tse koen Rauhalan kirjoitustyylin ja terminologian varsin kiehtovaksi, koska sanottu tuntuu kietovan sisäänsä niin laajoja alueita ja perustavanlaatuisia kysymyksiä. H etken häivähdys tai lupaus jostain pysyvästä elämän rannattomalla ulapalla on useinkin sangen tervetullutta hermolepoa. Tekstin viehättävyys perustunee myös suurelta osin siihen sisältyvään ihmiskeskeiseen ja ihmistä kunnioittavaan asenteeseen. 0 missa intuitiivisissa tulkinnoissani koen myös löytäväni tekstistä paikoittain tiettyä koskettavaa arvokkuutta.

Rauhalalle Iuonteenomainen ilmaisutapa on tinkimätöntä pyrkimystä selkeyteen ja käsitteelliseen yksiselitteisyyteen. Y leensähän käsitteiden, hypoteesien, mallien ja teorioiden suhde kuvattavaan tai selitettävään ilmiöön selviää vasta ajan ja syventyneen ymmärryksen myötä. Tällöin myös käsitteet ja termit muotoillaan tarkemmin uutta näkemystä vastaaviksi.

Fenomenologisen käsitteistön ja termistön epäempiirisyys sekä paikoin itseään määrittelevä kehämäisyys joutuvatkin usein kritiikin kohteiksi materialistiskausaalis-reduktionististen perusoletusten varaan rakentuneessa ja vallitsevassa tiedeperinteessämme. K un lisäksi Rauhalan esittämät vaihtoehtoiset näkemykset ihmistutkimuksen suuntaamisesta ongelmien perusluonnetta vastaavalla tavalla ovat sangen radikaaleja suhteessa vallitsevaan tilanteeseen, konflikteilta ei voitane yleisessä keskustelussa ja linjojen valinnassa tulevaisuudessakaan välttyä. Aika näyttänee, kuinka yleiset tieteelliselle tutkimukselle asetetut kriteerit ja vaatimukset sekä toisaalta Rauhalan ideogafisuutta, merkityksen ongelmaa ja subjektiivista maailmankuvaa painottavat tajuntatieteet tulevat toisiinsa suhteutumaan ja kehittymään.

\section{Jari Lehtonen}

Kirjoittajan pro gradu -työ vuodelta 1992, "Merkityksen ongelma inhimillisessä kokemuksessa Lauri Rauhalan holistisen ihmiskäsityksen valossa" ilmestyi Fenomenologisessa vuosikirjassa 1992, julkaisijana Suomen Fenomenologinen Instituutti. Vuosikirja kuuluu Tampereen yliopiston Filosofisia tutkimuksia sarjaan. 